\title{
Objectively measured active transportation to school and other destinations among 10-13 year olds
}

\author{
Gillian C. Williams ${ }^{1 *}$, Michael M. Borghese ${ }^{2}$ and lan Janssen ${ }^{1,2^{*}}$
}

\begin{abstract}
Background: Descriptive data on active transportation in children focuses on the trip to school and has relied on subjective reports. The purpose of this study was to use objective measures to describe total active transportation and active transportation to common destinations within children.
\end{abstract}

Methods: This was a descriptive study of 388 children aged 10-13 years from Kingston, Ontario, Canada. Participants wore a Garmin GPS watch during waking hours for seven days. Personal Activity Measurement Location System software used the GPS data to identify trips, time spent in each trip and the trip modality (walking, bicycle or vehicle). Google Maps software was used to identify trip destinations.

Results: A total of 8875 trips were identified. Most (69\%) trips were made by vehicle; $25 \%$ were made by walking and $6 \%$ by bicycle. Mean time spent in active transportation was $10.3 \mathrm{~min} /$ day $(95 \% \mathrm{Cl}: 7.4,14.5)$. Time spent in active transportation was higher for boys (12.1 min/day [95\% Cl: 8.8, 17.0) than for girls ( $8.5 \mathrm{~min} /$ day [95\% Cl: 6.1, 12.0]) and increased from $7.7 \mathrm{~min} /$ day $(95 \% \mathrm{Cl}: 5.5,11.1)$ at age 10 to $14.3 \mathrm{~min} /$ day $(95 \% \mathrm{Cl}: 10.3,19.9)$ at age 13 . Time spent in active transportation was lower in the winter by comparison to the other seasons. The four most common active transportation destinations were the participant's home, school, other people's homes, and parks or greenspace with 69\%, 39\%, 37\% and 32\% of participants walking or bicycling to these destinations at least once over the 7-day measurement period.

Conclusion: Over $65 \%$ of trips made and time spent travelling occurred in a vehicle. When active transportation was used, the most common destinations were home, school, other people's homes, and parks.

Keywords: Child, Physical activity, Transportation, Walking, Bicycling

\section{Background}

Physical activity benefits a child's physical, mental, and social health $[1,2]$. Active transportation, such as walking or cycling, can be an important source of physical activity [3-5]. Active transportation research among young people has focused on the trip to school. This research indicates that there has been a global decline in active transportation to school in recent decades [6], and that the proportion of students who actively commute to school varies greatly across countries (e.g., $80 \%$ in Zimbabwe to $13 \%$ in the United States) $[7,8]$.

\footnotetext{
*Correspondence: Gilliam.Williams@queensu.ca; lan.Janssen@queensu.ca ${ }^{1}$ Department of Public Health Sciences, Queen's University, Kingston, ON K7L 3N6, Canada

Full list of author information is available at the end of the article
}

Because previous research has focused on travel to school, childrens' active transportation habits to other destinations are largely unknown [9]. Furthermore, existing research has largely relied upon self- or parent-reported active transportation data [10]. Objectively measured data, research on total active transportation, and research on travel destinations other than school is needed. The recent availability of wearable Global Position System (GPS) loggers and Geographic Information System (GIS) software for the measurement of active transportation provides an opportunity to address these research gaps and limitations. Indeed, active transporation studies have starting using these objective measures [5, 11-15]. 
The purpose of this study was to use objective measures to describe total active transportation and active transportation to common travel destinations among a sample of 10-13 year olds from Kingston, Ontario, Canada. Consideration was given to the age and sex of the participants, the season in which active transportation was measured, and the travel mode (i.e., walking, bicycle, or vehicle).

\section{Methods}

\section{Participants}

This was a descriptive study of 10-13 years olds from Kingston, Ontario, Canada. Kingston is a mid-sized city (population 123,798) with a modest population density (273 people per $\mathrm{km}^{2}$ ) [16]. Approximately $15 \%$ of the population live in the urban core, $63 \%$ live in the suburbs, and the remaining $22 \%$ live in exurban and rural areas [17]. There is a large season variation in temperature in Kingston, with daily average temperatures ranging from $-7.0{ }^{\circ} \mathrm{C}$ in January to $21.5^{\circ} \mathrm{C}$ in July [18].

A sample of 458 children were recruited from the approximately 5000 eligible children [16]. Eligibility criteria were being aged 10-13 years, living and attending school in the city of Kingston, and ability to communicate in either of Canada's official languages (English or French). Data were collected between January 2015 and December 2016 and were balanced across the four seasons, age, sex, and proportional of the population of 10-13 year olds residing in each of the city's 12 electoral districts [16]. Children were compensated $\$ 40$ for completing the study. Participants and a parent/guardian provided consent. The study was approved by the General Research Ethics Board at Queen's University.

\section{Active transportation data collection and cleaning}

Participants were provided with verbal and written instructions on how to wear a Garmin Forerunner 220 GPS watch (Garmin Ltd., Schaffhausen, Switzerland). Participants wore the watch for 7 consecutive days. They were instructed to put on the watch shortly after waking, to turn on the GPS logger function, and to continue wearing the watch until bedtime, at which time they removed the watched so that its battery could be charged overnight. During waking hours the watch recorded their longitude and latitude coordinates approximately every $2 \mathrm{~s}$ to $2 \mathrm{~min}$ depending on satellite signal availability. The GPS data were downloaded from the watch using Garmin Connect software (Garmin Ltd., Schaffhausen, Switzerland) and then exported to Personal Activity and Location Measurement System (PALMS) software. The software filtered extreme observations and interpolating invalid GPS points caused by brief signal loss. PALMS provides a validated method for processing GPS data to objectively measure time spent in different transportation modes [19]. PALMS identified trips based on sequential GPS points spanning $\geq 100 \mathrm{~m}$ with a speed $\geq 1 \mathrm{~km} / \mathrm{h}$ over $\geq 3 \mathrm{~min}$ in duration. The software allowed for pauses in travel of up to $3 \mathrm{~min}$ to account for traffic lights and other brief stops. PALMS classified the modality of each trip as vehicle, bicycle, or walking based on travel speed. Trips with a 90th percentile of speed $\geq 25 \mathrm{~km} / \mathrm{h}$ were classified as vehicle trips, trips with a 90th percentile of speed $\geq 10 \mathrm{~km} / \mathrm{h}$ and $<25 \mathrm{~km} / \mathrm{h}$ were classified as bicycle trips, and trips with a 90th percentile of speed $\geq 1 \mathrm{~km} / \mathrm{h}$ and $<10 \mathrm{~km} / \mathrm{h}$ were classified as walking trips.

After PALMS software identified the trips and the modality of each trip, we used Google Fusion Tables (Google, Mountain View, California, USA) to visually inspect the GPS points of each trip which allowed us to remove false positive trips and identify the destination of each trip. False positives trips refer to trips identified by PALMS that reflect other movements such as outdoor play in the school yard. The 6595 trips that were identified by PALMS that occurred solely within a specific location (e.g., the school yard at recess) were classified as false positive trips and were deleted during the cleaning process.

During the cleaning process we identified the destination of each trip by examining its endpoint using satellite and street view images in Google Maps (Google, Mountain View, California, USA). Destinations were categorized based on the descriptions described in Table 1 . Note that trips to school were categorized based on the date/time of travel and whether or not it was the participant's school. Trips to school in the morning on school days were categorized in the "school" category. Trips leaving school at the end of the school day were captured in the "home" destination or wherever the participant travelled after school. Trips to school on non-school days, during the middle of the school day (e.g., field trips, leaving school property at lunch), and after school hours (e.g., returning to school for an event) were categorized as "school day trips and trips to school for non-curriculum purposes."

Note that active transportation trips with the same starting and end destination, such as hikes or walking around the neighbourhood, were also removed during the cleaning process as they were considered walking or bicycling for leisure rather than active transportation to a specific destination.

Next, the data were imported into SAS 9.4 statistical software (SAS Institute, Cary NC) for further processing and to calculate the number of minutes of active transportation. During this process we deleted 
Table 1 Description of trip destinations

\begin{tabular}{|c|c|}
\hline Destination & Description \\
\hline Home & The participant's primary or secondary residence. \\
\hline Other homes & Homes other than the primary or secondary residence. \\
\hline School bus stop & $\begin{array}{l}\text { Locations where participants travelled to so that they could be picked } \\
\text { up by a school bus. }\end{array}$ \\
\hline School & Trips to the participant's school immediately prior to the start of the school day. \\
\hline $\begin{array}{l}\text { School day trips and trips to school for } \\
\text { non-curriculum purposes }\end{array}$ & $\begin{array}{l}\text { Trips to school during the school day (e.g., returning to school from a field trip or } \\
\text { medical appointment), or returning to school in the evenings or on non-school } \\
\text { days (e.g., for an after-school event, to play on school grounds on the weekend). }\end{array}$ \\
\hline Parks or greenspace & City parks, undeveloped greenspace, or conservation areas. \\
\hline Recreation facilities & $\begin{array}{l}\text { Government and commercial recreation and sport facilities (e.g., arenas, sports fields, } \\
\text { gymnastics club). }\end{array}$ \\
\hline Retail locations & $\begin{array}{l}\text { Supermarkets, grocery stores, convenience stores, gas stations, big box stores, strip } \\
\text { malls, stand-alone stores, downtown stores, and shopping malls. }\end{array}$ \\
\hline Food service locations & $\begin{array}{l}\text { Fast food restaurants, full service restaurants, coffee shops, and dessert and ice } \\
\text { cream shops. }\end{array}$ \\
\hline Community locations & $\begin{array}{l}\text { Entertainment or cultural facilities, churches or other places of worship, community } \\
\text { centres, libraries. }\end{array}$ \\
\hline Other & $\begin{array}{l}\text { Health care facilities, other schools (not the school where the participant was enrolled), } \\
\text { transit stations, police station etc. }\end{array}$ \\
\hline
\end{tabular}

data from days with $<10 \mathrm{~h}$ of GPS data (i.e., invalid days) and participants $(n=70)$ with $<4$ valid days. This step is consistent with data processing done with accelerometer measures of physical activity $[20,21]$. The SAS program then determined the total number of trips, the total duration of each trip (based on the times that the GPS points of the trip start and end points were recorded), and total daily time spent in trips separately by trip modality and destination.

The reliability of the protocol used to clean the GPS data and identify trip destinations was determined by repeating all data cleaning steps for 50 participants in triplicate. One observer cleaned the data twice and a second observer cleaned the data a third time. Mean minutes/day in active transportation were consistent across all three cleaning scenarios: 14.8 (95\% CI: 12.3, 17.3) for the initial clean by observer 1, 15.9 (95\% CI: 13.5, 18.3) for the second cleaning by observer 1 , and 14.7 (95\% CI: 12.7, 16.8) for the clean by the second observer. Intra-rater percent agreement for destinations was 90\% and inter-rater agreement was $88 \%$.

\section{Sociodemographic and covariate data}

Sociodemographic characteristics including age, sex, and race (white, other) of the participant, family structure (number of parents and siblings in the household), family income, and parental education were obtained from a parent survey. Season of participation was categorized based on equinox and solstice dates. The body mass index was calculated based on heights and weights measured using a stadiometer and digital scale, respectively. The World Health Organization references were used to categorize participants as having a non-overweight (thin + normal), overweight, or obese body mass index [22].

\section{Statistical analysis}

Data were analyzed using SAS 9.4. Transportation behaviours were presented in several ways: the number of trips made, the proportion of participants who travelled to different destinations over the 7 day measurement period, the proportion of trips that were made by walking or bicycling, and average daily time spent traveling using different travel modes. An initial examination of the data revealed that $10 \%$ of participants did not have any active transportation trips and that the active transportation data could not be transformed to follow a normal distribution. Therefore, a two-part modelling strategy was used to estimate average min/day of active transportation. This is a strategy commonly used for health-care cost data which is similarly distributed [23, 24]. In the first part of the two-part model, logistic regression was used to model the probability of the presence of any active transportation minutes. In the second part of the two-part model, a generalized linear model was used to model active transportation minutes in participants who engaged in any active transportation. To fit this model the proc genmod procedure was used with a logarithmic link function and gamma distribution. All models were adjusted for age, sex and season. Other covariates (race, number of parents in household, number of siblings in household, family income, and 
parental education) were entered in the model using backwards selection methods and were retained based on a significance level of $p<0.1$ in either the logistic regression or general linear model. The mean daily time spent engaged in active transportation was calculated by multiplying the estimates from the two models together. ANOVA and Bonferroni post hoc comparison tests were used to compare active transportation by age, sex, and season for destinations with a daily average $>1 \mathrm{~min}$.

\section{Results}

\section{Descriptive characteristics}

Seventy participants were removed during data processing due to insufficient GPS data. This left a final sample of 388. Among these 388 participants, $5 \%$ had 4 valid days of GPS data, $14 \%$ had 5 valid days, 31\% had 6 valid days, and $49 \%$ had 7 valid days. On valid days there was an average of $13.7 \mathrm{~h}$ (95\% CI: 13.6, 13.8) of GPS data. Descriptive characteristics of the participants are in Table 2. Approximately half were boys (51\%) and participants were evenly distributed across ages and seasons. The majority were white (87\%) and lived in a dual parent household (86\%).

\section{Proportion of trips made using active transportation}

After removal of 6595 false positive trips during data cleaning, a total of 8875 trips remained. Most (69\%) of these trips were made by vehicle; $25 \%$ were made by walking and $6 \%$ by bicycle. Thirty-eight (10\%) participants did not have any active trips and 249 (64\%) did not have any bicycle trips.

Table 3 provides information on trips to different destinations. In the total sample there were a total of 366 trips made for each 100 observation days. The most common travel destinations were the participant's own home (119 trips per 100 days), trips to school to start the school day (54 trips per 100 days), retail locations (45 trips per 100 days), and other people's homes (32 trips per 100 days). The most common active transportation destinations were the participant's own home, their own school, other people's homes, and parks or greenspace with $69 \%, 39 \%, 37 \%$ and $32 \%$ of participants walking or bicycling to these destinations at least once over the 7-day measurement period. Approximately $65 \%$ of all active transportation trips were made to one of these four destinations. Fewer than $25 \%$ of participants made an active transportation trip to a retail location, restaurant, recreation facility, community centre, or other community locations (e.g., place of worship, arts or entertainment venue) and $<25 \%$ of trips to these locations were made using active transportation.
Table 2 Participant characteristics

\begin{tabular}{|c|c|c|}
\hline Characteristic & Number & Percent \\
\hline \multicolumn{3}{|l|}{ Sex } \\
\hline Boy & 197 & 50.8 \\
\hline Girl & 191 & 49.2 \\
\hline \multicolumn{3}{|l|}{ Age (years) } \\
\hline 10 & 94 & 24.2 \\
\hline 11 & 97 & 25.0 \\
\hline 12 & 101 & 26.0 \\
\hline 13 & 96 & 24.7 \\
\hline \multicolumn{3}{|l|}{ BMI } \\
\hline Not overweight & 287 & 74.0 \\
\hline Overweight & 62 & 16.0 \\
\hline Obese & 39 & 10.1 \\
\hline \multicolumn{3}{|l|}{ Race } \\
\hline White & 336 & 86.6 \\
\hline Other & 52 & 13.4 \\
\hline \multicolumn{3}{|l|}{ Season of Participation } \\
\hline Winter & 101 & 26.0 \\
\hline Spring & 99 & 25.5 \\
\hline Fall & 90 & 23.2 \\
\hline Summer & 98 & 25.3 \\
\hline \multicolumn{3}{|c|}{ Number of Parents in Household } \\
\hline Dual Parent & 335 & 86.3 \\
\hline Single Parent & 50 & 12.9 \\
\hline No response & 3 & 0.8 \\
\hline \multicolumn{3}{|c|}{ Number of Siblings in Household } \\
\hline 0 & 47 & 12.1 \\
\hline 1 & 196 & 50.5 \\
\hline 2 & 101 & 26.0 \\
\hline $3+$ & 44 & 11.4 \\
\hline \multicolumn{3}{|c|}{ Family Income (\$ CDN per year) } \\
\hline 50,000 & 57 & 14.7 \\
\hline $50,001-100,000$ & 112 & 28.9 \\
\hline$>100,000$ & 176 & 45.4 \\
\hline No response & 43 & 11.1 \\
\hline \multicolumn{3}{|l|}{ Parental Education } \\
\hline High school or less & 32 & 8.3 \\
\hline 2-year college & 115 & 29.6 \\
\hline 4-year college/university & 241 & 62.1 \\
\hline
\end{tabular}

Time spent in active transportation

On average, participants spent $10.3 \mathrm{~min} /$ day (95\% CI: 7.4 , 14.5) participating in active transportation. The average daily time spent walking and bicycling for travel were $9.4 \mathrm{~min} /$ day $(95 \% \mathrm{CI}: 7.3,12.2)$ and $1.8 \mathrm{~min} /$ day (95\% CI: $1.2,2.8$ ), respectively. This is in 
Table 3 Descriptive information on trips and trips to different destinations within the entire sample $(n=388)$

\begin{tabular}{|c|c|c|c|c|c|c|}
\hline Destination & $\begin{array}{l}\%(95 \% \mathrm{Cl}) \text { who } \\
\text { travelled to destination } \\
\text { using any mode }\end{array}$ & $\begin{array}{l}\%(95 \% \mathrm{Cl}) \text { who } \\
\text { travelled to destination } \\
\text { using active travel }\end{array}$ & $\begin{array}{l}\text { \# of trips to } \\
\text { destination (per } \\
100 \text { person days) } \\
\end{array}$ & $\begin{array}{l}\% \text { of trips to } \\
\text { destination made } \\
\text { by walking }\end{array}$ & $\begin{array}{l}\% \text { of trips to } \\
\text { destination } \\
\text { made by bicycle }\end{array}$ & $\begin{array}{l}\text { Mean }(95 \% \mathrm{Cl}) \text { minutes/ } \\
\text { day of active travel to } \\
\text { destination }\end{array}$ \\
\hline $\begin{array}{l}\text { All } \\
\text { destinations }\end{array}$ & 100 & $90.0(87.2,93.2)$ & 366 & 31.1 & 6.3 & $10.3(7.4,14.5)^{a, b, c}$ \\
\hline Home & 100 & $69.3(64.7,73.9)$ & 119 & 25.2 & 6.6 & $3.1(2.1,4.5)^{a, b, c}$ \\
\hline $\begin{array}{l}\text { Other } \\
\text { people's } \\
\text { homes }\end{array}$ & $71.9(67.4,76.4)$ & $36.6(31.8,41.4)$ & 32 & 24.3 & 11.0 & $1.0(0.7,1.5)^{\mathrm{a}}$ \\
\hline Bus stop & $20.6(16.6,24.7)$ & $14.2(10.7,17.7)$ & 16 & 42.8 & 0.5 & $0.2(0.1,0.3)^{a}$ \\
\hline $\begin{array}{l}\text { School to } \\
\text { start school } \\
\text { day }\end{array}$ & $82.5(78.7,86.3)$ & $38.7(33.8,43.5)$ & 54 & 29.2 & 7.1 & $2.1(1.5,3.0)^{a, b}$ \\
\hline $\begin{array}{l}\text { Other trips } \\
\text { to school }\end{array}$ & $33.0(28.3,37.7)$ & $23.5(19.2,27.7)$ & 10 & 57.2 & 13.5 & $0.7(0.5,1.0)^{a}$ \\
\hline $\begin{array}{l}\text { Parks or } \\
\text { greenspace }\end{array}$ & $46.4(41.4,51.4)$ & $32.2(27.5,36.9)$ & 16 & 11.7 & 14.8 & $1.0(0.6,1.5)^{\mathrm{a}, \mathrm{b}}$ \\
\hline $\begin{array}{l}\text { Recreation } \\
\text { facilities }\end{array}$ & $68.3(63.6,72.9)$ & $17.0(13.3,20.8)$ & 30 & 13.1 & 3.4 & $0.5(0.3,0.8)^{a}$ \\
\hline $\begin{array}{l}\text { Retail } \\
\text { locations }\end{array}$ & $84.3(80.6,87.9)$ & $24.7(20.4,29.1)$ & 45 & 12.7 & 3.0 & $0.8(0.5,1.1)^{\mathrm{a}}$ \\
\hline $\begin{array}{l}\text { Food } \\
\text { service } \\
\text { locations }\end{array}$ & $53.1(48.1,58.1)$ & $16.0(12.3,19.6)$ & 15 & 22.4 & 2.2 & $0.5(0.3,0.8)^{a}$ \\
\hline $\begin{array}{l}\text { Community } \\
\text { locations }\end{array}$ & $47.4(42.4,52.4)$ & $11.3(8.2,14.5)$ & 13 & 13.8 & 3.8 & $0.4(0.2,0.6)^{a}$ \\
\hline Other & $46.6(41.7,51.6)$ & $15.2(11.6,18.8)$ & 17 & 19.8 & 5.4 & $0.3(0.2,0.5)^{\mathrm{a}}$ \\
\hline
\end{tabular}

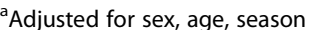

${ }^{b}$ Adjusted for number of siblings in household

${ }^{\mathrm{C}}$ Adjusted for single or dual parent household

contrast with a mean of $57.4 \mathrm{~min} /$ day $(95 \% \mathrm{CI}: 47.6$, 69.2) of vehicle travel. The participant's own home was the destination with the highest minutes of active transportation with a daily average of 3.1 (95\% CI: $2.1,4.5)$ minutes, followed by school to start the school day (2.1 min [95\% CI: 1.5, 3.0]) and other people's homes (1.0 min [95\% CI: 0.7, 1.5]). Mean min/ day of active transportation was $<1$ min for all other destinations.

Table 4 shows the average daily minutes of active transportation to destinations with a mean $>1 \mathrm{~min} /$ day according to age, sex and season. Mean daily minutes of active transportation for boys $(12.1 \mathrm{~min} /$ day [95\% CI: 8.8, 17.0]) was significantly higher than for girls $(8.5 \mathrm{~min} /$ day [95\% CI: 6.1, 12.0]). Time spent in active transportation increased from $7.7 \mathrm{~min} /$ day $(95 \%$ CI: $5.5,11.1$ ) at age 10 to $14.3 \mathrm{~min} /$ day (95\% CI: $10.3,19.9)$ at age 13. Time spent in active transportation was statistically lower in the winter by comparison to the other 3 seasons. Similar patterns to those described for total active transportation were observed for active transportation to the most common active transportation destinations (Table 3).

\section{Discussion}

This study objectively measured active transportation levels and destinations among a diverse sample of 1013 year olds from Kingston, Ontario, Canada. Overall, $10 \%$ of participants did not have any active transportation trips over the course of the week and only $37 \%$ of trips were made using active transportation. Participants spent $10 \mathrm{~min} /$ day engaged in active transportation. Home, school and other people's homes were the most common active travel destinations. Significant differences in active transportation were found by age, sex and season.

Only a few prior studies have described objectively measured active transportation data among children and youth $[5,11-15]$. In our study, $90 \%$ of participants engaged in active transportation at least once over the course of the week, which is comparable to a study of 12-16 year old Americans where $77 \%$ engaged in active transportation over a week [11]. In that American study $43 \%$ of the trips were made using active transportation, which is similar to the value of $37 \%$ found in our study, but much lower than the value of $74 \%$ observed among $14-18$ year 
Table 4 Sex, age, and season difference in minutes/day spent in active travel by travel destination for those destinations where the mean active travel time was $>1$ min/day

\begin{tabular}{|c|c|c|c|c|}
\hline \multirow[t]{2}{*}{ Characteristic } & \multicolumn{4}{|l|}{ Travel destination } \\
\hline & All destinations ${ }^{h, i, j}$ & Participant's own home $e^{h, i, j}$ & Other people's homes ${ }^{h}$ & School to start school day ${ }^{h, i}$ \\
\hline Total $(n=388)$ & $10.3(7.4,14.5)$ & $3.1(2.1,4.5)$ & $1.0(0.7,1.5)$ & $2.1(1.5,3.0)$ \\
\hline \multicolumn{5}{|l|}{ Sex } \\
\hline Boys $(n=197)$ & $12.1(8.8,17.0)$ & $3.7(2.6,5.4)$ & $1.2(0.8,1.7)$ & $2.2(1.6,3.1)$ \\
\hline Girls $(n=191)$ & $8.5(6.1,12.0)^{a}$ & $2.4(1.6,3.5)^{\mathrm{a}}$ & $0.8(0.6,1.3)$ & $1.9(1.3,2.7)$ \\
\hline \multicolumn{5}{|l|}{ Age } \\
\hline $10(n=94)$ & $7.7(5.5,11.1)$ & $2.2(1.5,3.4)$ & $0.7(0.5,1.1)$ & $2.0(1.4,2.7)$ \\
\hline $11(n=97)$ & $9.7(6.9,13.7)$ & $2.8(2.0,4.1)$ & $1.1(0.7,1.5)$ & $1.7(1.2,2.4)$ \\
\hline $12(n=101)$ & $9.6(7.0,13.4)$ & $3.1(2.2,4.5)$ & $1.0(0.7,1.6)$ & $2.0(1.4,2.9)$ \\
\hline $13(n=96)$ & $14.3(10.3,19.9)^{b, c, d}$ & $4.0(2.8,5.8)^{b, c}$ & $1.2(0.8,1.7)$ & $2.5(1.8,3.6)$ \\
\hline \multicolumn{5}{|l|}{ Season } \\
\hline Winter $(n=101)$ & $6.4(4.7,8.9)$ & $2.1(1.4,3.1)$ & $0.4(0.3,0.6)$ & $1.6(1.1,2.2)$ \\
\hline Spring $(n=99)$ & $12.6(9.2,17.3)^{\mathrm{e}}$ & $3.6(2.6,5.2)^{\mathrm{e}}$ & $1.2(0.8,1.7)^{\mathrm{e}}$ & $2.3(1.6,3.4)$ \\
\hline Summer $(n=90)$ & $12.2(8.7,17.2)^{\mathrm{e}}$ & $3.0(2.1,4.4)^{\mathrm{e}}$ & $1.5(1.0,2.1)^{\mathrm{e}}$ & $1.5(1.0,2.1)$ \\
\hline Fall $(n=98)$ & $10.4(7.3,15.1)^{\mathrm{e}}$ & $3.5(2.4,5.1)^{\mathrm{e}}$ & $1.0(0.7,1.4)$ & $2.7(2.0,3.9)^{9}$ \\
\hline
\end{tabular}

${ }^{a}$ Significantly different from boys $(p<0.05)$

${ }^{\mathrm{b}}$ Significantly different from 10 year olds $(p<0.05)$

'Significantly different from 11 year olds $(p<0.05)$

${ }^{\mathrm{d}}$ Significantly different from 12 year olds $(p<0.05$

esignificantly different from winter $(p<0.05)$

fSignificantly different from spring $(p<0.05)$

${ }^{9}$ Significantly different from summer $(p<0.05)$

${ }^{\mathrm{h}}$ Adjusted for sex, age, season

'Adjusted for number of siblings

${ }^{\mathrm{j}}$ Adjusted for single or dual parent household

olds in Portugal [5]. The average time spent in active transportation is also higher in children from other European countries than in our Canadian sample. Specifically, the average daily time spent in active transportation was $22.5 \mathrm{~min} /$ day in a sample of 10 13 year old Belgian children [15] and $19.0 \mathrm{~min} /$ day in a sample of 11-16 year old Danish youth [14]. This is consistent with self-reported active transportation data which consistently show that by comparison to North America, a greater proportion of children from European countries walk or bicycle to school [10, 25, 26]. The differences in active travel between North America and Europe reflect policies on pedestrian safety, cultural norms and the compact nature of European cities that allow for short trips.

In terms of travel destinations, parental reported data on a sample of 7-12 year olds from Canada and the United States suggested that $28 \%$ walked or bicycled to someone else's home at least three times per week and that $21 \%$ walked or bicycled to a park at least 3 times per week [27]. In our study of 10-13 year olds, 37\% and 32\% walked or bicycled to these destinations at least once in the week-long data collection period. We also found that $39 \%$ of participants had at least one active trip to their school to start the school day. This is in line with self- or parental-reported estimates in 5- to 17-year-olds in Canada: $42 \%$ use exclusively active transportation or a combination of active and passive transportation to travel to and from their school [9]. It is important to note that trips home from school were not categorized as school trips in our study as the categorization was based on the destination and not starting point of the trip. Therefore, we likely did not capture all students who use active transportation from school because the proportion of children who walk or bicycle home from school in the afternoon is about $10 \%$ higher than the proportion who walk or bicycle to school in the morning [28].

Our findings that active transportation was higher in boys than girls and increased from age 10 to 13 are consistent with what has been found in the literature based on questionnaire measures. Boys have consistently been found to engage in more active transportation than girls $[29,30]$. Active transportation has been found to increase with age, peak during adolescence then decline [30-32]. In contrast with our results, where there was clear seasonal variation in active transportation, previous studies conducted in Ontario, Canada have not found an effect of the seasons on active transportation to school $[30,33]$. However, these studies only considered data collected over the course of a school year or less. 
The findings of our study have implications for public health practice. Specifically, our findings suggest that interventions should consider active transportation to destinations other than school, the focal point of almost all active travel interventions in children [34], and be cognisant of sex disparities and the influence of season on active transportation. The average of $11 \mathrm{~min} /$ day of active transportation in this study represents only $18 \%$ of the target needed to meet the public health recommendation of $60 \mathrm{~min} /$ day of moderate-to-vigorous physical activity [35]. Other data from the study sample that was not presented in this paper indicates that they accumulated an average of $54 \mathrm{~min} /$ day of moderate-to-vigorous activity, which is within a few minutes of the moderateto-vigorous activity levels observed in a nationally representative of Canadian children [36]. Collectively, these observations suggest that even modest increases in active transportation would result in a substantial increase in the proportion of children meeting public health recommendations for physical activity.

Our findings also have implications for the measurement of active transportation in research settings. Approximately $40 \%$ of trips originally identified by the PALMS software were false positive trips. Play in the school yard during recess or leisure trips (e.g., walking around the neighbourhood with the same starting point and destination) are examples of physical activities that were commonly identified as trips by PALMS software and which we needed to reclassify after the automated PALMS processing steps were completed. Future research is needed to determine the most accurate and most feasible ways to process the GPS data post-PALMS.

There are some limitations of this study. First, 15\% of participants did not have adequate GPS data to be included in the analysis. Although there were no significant differences in the descriptive characteristics of those included and those excluded from the analyses, it is possible that their active transportation differed. Second, trips $<100 \mathrm{~m}$ long and lasting $<3 \mathrm{~min}$ were not captured by PALMS software. Therefore, short trips, such as to a nearby house or bus stop, were missed. Third, based on existing precedence in the physical activity field [21], participants could have as few as 4 days of valid data (i.e., $\geq 10 \mathrm{~h}$ of GPS wear time) to be included in the analyses. That would have led to misclassification had these 4-7 days did not reflect their habitual active transportation. Finally, these results are limited to 10-13 year olds from Kingston, Ontario, Canada.

\section{Conclusion}

The use of objective measures to capture active transportation to a variety of destinations among children fills major calls for research in the active transportation field
[9]. In this study of 10-13 year olds, approximately 1 in every 3 trips was made using active transportation. Children spent an average of $11 \mathrm{~min} /$ day walking or bicycling vs. $57 \mathrm{~min} /$ day travelling in a motorized vehicle. Home, school and other people's homes were the destinations with the most active transportation minutes. Future research should continue to use objective measures but consider a greater age range as well as greater geographic diversity.

\section{Abbreviations \\ GIS: Geographic information systems; GPS: Global position system \\ Acknowledgements \\ The authors would like to thank the participants for their commitment to the study, the project coordinator, and the many graduate students and research assistants who assisted with data collection, processing, and cleaning.}

Ethics approval and consent to participation

All participants and a parent/guardian provided informed consent prior to participation. The study received ethics approval from the Queen's University General Research Ethics Board.

Funding

This study was funded by a grant from the Heart and Stroke Foundation of Canada. IJ was funded by a Canada Research Chair award. GW was supported by an Ontario Graduate Scholarship.

\section{Availability of data and materials}

The datasets generated and/or analysed during the current study are not publicly available, due to the private and sensitive nature of some of the data that were collected, but are available from the corresponding author on reasonable request.

\section{Authors' contributions}

GW and IJ contributed to the idea for this paper. GW developed the protocol for cleaning the GPS data, assisted with the data collection, completed the statistical analyses, and wrote the first draft of the manuscript. MB assisted with data collection, data cleaning, statistical analyses, and edited the manuscript for important intellectual content. IJ conceived and designed the Active Play Study, obtained funding for and oversaw the study, provided advice and guidance on the statistical analyses, and edited the manuscript for important intellectual content. All authors read and approved the final manuscript.

\section{Consent for publication}

The authors have all reviewed and approved of the final version of the manuscript.

\section{Competing interests}

The authors declare that they have no competing interests.

\section{Publisher's Note}

Springer Nature remains neutral with regard to jurisdictional claims in published maps and institutional affiliations.

\section{Author details}

'Department of Public Health Sciences, Queen's University, Kingston, ON K7L 3N6, Canada. ${ }^{2}$ School of Kinesiology and Health Studies, Queen's University, Kingston, ON K7L 3N6, Canada.

Received: 22 September 2017 Accepted: 11 December 2017

Published online: 19 January 2018

References

1. Janssen I, Leblanc AG. Systematic review of the health benefits of physical activity and fitness in school-aged children and youth. Int J Behav Nutr Phys Act. 2010;7:40

2. Poitras VJ, Gray CE, Borghese MM, Carson V, Chaput J-P, Janssen I, Katzmarzyk PT, Pate RR, Gorber SC, Kho ME, et al. Systematic review of the 
relationships between objectively measured physical activity and health indicators in school-aged children and youth. Appl Physiol Nutr Metab. 2016:41:S197-239

3. Faulkner GEJ, Buliung RN, Flora PK, Fusco C. Active school transport, physical activity levels and body weight of children and youth: a systematic review. Prev Med. 2009:48:3-8.

4. Smith L, Sahlqvist S, Ogilvie D, Jones A, Griffin SJ, van Sluijs E. Is active travel to non-school destinations associated with physical activity in primary school children? Prev Med. 2012;54:224-8.

5. Pizarro AN, Schipperijn J, Andersen HB, Ribeiro JC, Mota J, Santos MP. Active commuting to school in Portuguese adolescents: using PALMS to detect trips. J Transp Health. 2016;3:297-304.

6. Tremblay MS, Gray CE, Akinroye K, Harrington DM, Katzmarzyk PT, Lambert EV, Liukkonen J, Maddison R, Ocansey RT, Onywera VO, et al. Physical activity of children: a global matrix of grades comparing 15 countries. J Phys Act Health. 2014;11:S113-25.

7. Katzmarzyk PT, Denstel KD, Beals K, Bolling C, Wright C, Crouter SE, Mckenzie TL, Pate RR, Saelens BE, Staiano AE, et al. Results from the United States of America's 2016 report card on physical activity for children and youth. J Phys Act Health. 2016;13:307-13.

8. Zaabi MA, Shah SM, Sheek-Hussein M, Abdulle A, Junaibi AA, Loney T. Results from the United Arab Emirates' 2016 report card on physical activity for children and youth. J Phys Act Health. 2016;13:299-306.

9. Barnes JD, Cameron C, Carson V, Chaput J-P, Faulkner GEJ, Janson K, Janssen I, Kramers R, Leblanc AG, Spence JC, et al. Results from Canada's 2016 Participation report card on physical activity for children and youth. J Phys Act Health. 2016;13:110-6.

10. D'Haese S, Vanwolleghem G, Hinckson E, De Bourdeaudhuij I, Deforche B, Van Dyck D, Cardon G. Cross-continental comparison of the association between the physical environment and active transportation in children: a systematic review. Int J Behav Nutr Phys Act. 2015;12:145.

11. Carlson JA, Saelens BE, Kerr J, Schipperijn J, Conway TL, Frank LD, Chapman JE, Glanz K, Cain KL, Sallis JF. Association between neighborhood walkability and GPS-measured walking, bicycling and vehicle time in adolescents. Health Place. 2015;32:1-7.

12. Helbich M, Zeylmans van Emmichoven MJ, Dijst MJ, Kwan M-P, Pierik FH, de Vries SI. Natural and built environmental exposures on children's active school travel: a Dutch global positioning system-based cross-sectional study. Health Place. 2016;39:101-9.

13. Stewart T, Duncan S, Schipperijn J. Adolescents who engage in active school transport are also more active in other contexts: a space-time investigation. Health Place. 2017;43:25-32.

14. Klinker C, Schipperijn J, Kerr J, Kjaer Ersbø\|l A, Troelsen J, Aaron Hipp J, McCormick LC, Hirsch JA. Context-specific outdoor time and physical activity among school-children across gender and age: using accelerometers and GPS to advance methods. Front Public Health. 2014;2:20.

15. Vanwolleghem G, Schipperijn J, Gheysen F, Cardon G, De Bourdeaudhuij I, Dyck DV. Children's GPS-determined versus self-reported transport in leisure time and associations with parental perceptions of the neighborhood environment. Int J Health Geogr. 2016;15:16.

16. Canada S. 2011 Census of population. Statistics Canada Catalogue no 98-312-XCB2011009 2012.

17. Gordon DA. Canadian Suburbs [https://qshare.queensu.ca/Users01/gordond/ Suburbs/] (Accessed 15 Nov 2017).

18. Environment and Climate Change Canada. 1981-2010 Climate Normals \& Averages [http://climate.weather.gc.ca/climate_normals/index_e.html] (Accessed 15 Nov 2017).

19. Carlson JA, Jankowska MM, Meseck K, Godbole S, Natarajan L, Raab F, Demchak B, Patrick K, Kerr J. Validity of PALMS GPS scoring of active and passive travel compared with SenseCam. Med Sci Sports Exerc. 2015:47:662-7.

20. Troiano RP, Berrigan D, Dodd KW, Mâsse LC, Tilert T, Mcdowell M. Physical activity in the United States measured by accelerometer. Med Sci Sports Exerc. 2008:40:181-8.

21. Colley R, Gorber SC, Tremblay MS. Quality control and data reduction procedures for accelerometry-derived measures of physical activity. Health Rep. 2010;21:63-8.

22. de Onis M, Onyango AW, Borghi E, Siyam A, Nishida C, Siekmann J. Development of a WHO growth reference for school-aged children and adolescents. Bull World Health Organ. 2007:85:660-7.
23. Diehr D, Yanez A, Ash M, Nornbrook DY. Methods for analyzing health care utilization and costs. Annu Rev Public Health. 1999:20:125-44.

24. Janssen I, Lam M, Katzmarzyk PT. Influence of overweight and obesity on physician costs in adolescents and adults in Ontario, Canada. Obes Rev. 2009;10:51-7

25. Bassett DR, Pucher J, Buehler R, Thompson DL, Crouter SE. Walking, cycling, and obesity rates in Europe, North America, and Australia. J Phys Act Health. 2008:5:795-814.

26. Pucher J, Dijkstra L. Making walking and cycling safer: lessons from Europe. Transp Q. 2000;54:25-50.

27. Janssen I. Hyper-parenting is negatively associated with physical activity among 7-12 year olds. Prev Med. 2015;73:55-9.

28. Wong BY-M, Faulkner G, Buliung R, Irving H. Mode shifting in school travel mode: examining the prevalence and correlates of active school transport in Ontario, Canada. BMC Public Health. 2011:11:1-12.

29. Larsen K, Gilliland J, Hess P, Tucker P, Irwin J, He M. The influence of the physical environment and sociodemographic characteristics on children's mode of travel to and from school. Am J Public Health. 2009; 99:520-6.

30. Robertson-Wilson JE, Leatherdale ST, Wong SL. Social-ecological correlates of active commuting to school among high school students. J Adolesc Health. 2008:42:486-95.

31. Oliver M, Badland H, Mavoa S, Witten K, Kearns R, Ellaway A, Hinckson E, Mackay L, Schluter PJ. Environmental and socio-demographic associates of children's active transport to school: a cross-sectional investigation from the URBAN study. Int J Behav Nutr Phys Act. 2014;11:70.

32. Pabayo R, Gauvin L, Barnett TA. Longitudinal changes in active transportation to school in Canadian youth aged 6 through 16 years. Pediatrics. 2011;128:e404-13.

33. Mitra R, Faulkner G. There's no such thing as bad weather, just the wrong clothing: climate, weather and active school transportation in Toronto, Canada. Can J Public Health. 2012;103:S35-41.

34. Carlin A, Murphy MH, Gallagher AM. Do interventions to increase walking work? A systematic review of interventions in children and adolescents. Sports Med. 2016:46:515-30.

35. Tremblay MS, Carson V, Chaput J-P, Gorber SC, Dinh T, Duggan M, Faulkner G, Gray CE, Gruber R, Janson K, et al. Canadian 24-hour movement guidelines for children and youth: an integration of physical activity, sedentary behaviour, and Sleep. Appl Physiol Nutr Metab. 2016; 41:S311-27.

36. Colley RC, Garriguet D, Janssen I, Craig CL, Clarke J, Tremblay MS. Physical activity of Canadian children and youth: accelerometer results from the 2007 to 2009 Canadian Health Measures Survey. Health Rep. 2011;22:15-23.

\section{Submit your next manuscript to BioMed Central and we will help you at every step:}

- We accept pre-submission inquiries

- Our selector tool helps you to find the most relevant journal

- We provide round the clock customer support

- Convenient online submission

- Thorough peer review

- Inclusion in PubMed and all major indexing services

- Maximum visibility for your research

Submit your manuscript at www.biomedcentral.com/submit 